\title{
PEMBERDAYAAN MASYARAKAT DALAM PENERAPAN SISTEM PERTANIAN ORGANIK DI DESA SUMBER SARI KECAMATAN CIPARAY KABUPATEN BANDUNG
}

\author{
Betty Natalie Fitriatin, Emma Trinurani Sofyan dan Anny Yuniarti \\ Departemen Ilmu Tanah dan Sumberdaya Lahan, Fakultas Pertanian Universitas Padjadjaran \\ E-mail: betty.natalie@unpad.ac.id
}

\begin{abstract}
ABSTRAK. Pemberian yang ekstensif bahan-bahan kimia terhadap tanah dan tanaman akan menyebabkan terjadinya penurunan produktivitas lahan yang selanjutnya menurunkan produksi tanaman. Salah satu upaya pemulihan lahan secara berkelanjutan dengan menerapkan sistem pertanian organik antara lain dengan pemberian pupuk organik yang berbahan dasar dari limbah pertanian dan sampah rumah tangga yang banyak tersedia di wilayah namun masyarakat belum memanfaatan secara optimal. Tujuan kegiatan pengabdian kepada masyarakat yang dilaksanakan di Desa Sumber Sari Kecamatan Ciparay ini memberikan informasi dan keterampilan kepada masyarakat melalui penyuluhan dalam bentuk ceramah, praktek pembuatan pupuk organik dan hayati serta praktek lapangan (demplot tentang menerapkan system pertanian organik untuk meningkatkan dan mempertahankan kualitas tanah dengan memanfaatkan input lokal dengan biaya yang relatif murah dan praktis. Selain itu, penerapan sistem pertanian organik dengan memanfaakan limbah pertanian dapat meningkatkan produksi tanaman serta mengurangi ketergantungan pada pupuk buatan dan biaya subsidi pupuk yang terus meningkat. Percobaan lapangan sebagai demplot terdiri atas tiga perlakuan yaitu budidaya padi sawah varietas Ciherang yaitu sistem organik (100\% organik); semi organik (50\% anorganik $+50 \%$ organik) dan cara konvensional (100\% anorganik). Hasil panen padi sawah pada demplot ini menunjukkan bahwa perlakuan semi organik memberikan hasil panen (berat gabah) tertinggi dibandingkan perlakuan organik dan konvensional (100\% anorganik)
\end{abstract}

Kata Kunci: padi; pertanian orgnik; pupuk organik

ABSTRACT. The extensive application of chemicals to the soil and plants will cause a decrease in land productivity which in turn reduces crop production. One of the efforts to sustainably recover land by application an organic farming system is the provision of organic fertilizer based on agricultural waste and household waste that are widely available in the region but the community has not utilized it optimally. The purpose of community service activities carried out in Sumber Sari Village, Ciparay Subdistrict, is to provide information and skills to the community through counseling by lectures, practices of making organic and biofertilizers and field practices (demonstration plots about implementing organic farming systems to improve and maintain soil quality by utilizing local inputs with relatively cheap and practical costs. Futhermore, the application of organic farming systems by utilizing agricultural waste can increase crop production and reduce dependence on chemical fertilizers and the cost of fertilizer subsidies. The field experiment as a demonstration plot consisted of three treatments, used Ciherang variety of rice. The treatment were organic systems (100\% organic); semi-organic (50\% inorganic $+50 \%$ organic) and conventional methods (100\% inorganic). The result showed that semi-organic treatment gives the highest yield (grain weight) than organic and conventional treatments (100\% inorganic)

Key words: rice; organic farming; organic fertilizer

\section{PENDAHULUAN}

Kehawatiran akan pencemaran lingkungan akibat penggunaan berbagai bahan kimia terutama pupuk anorganik dan pestisida sintetik serta alasan kesehatan dan kelestarian alam/lingkungan menjadikan pertanian organik sebagai salah satu alternatif pertanian modern. Pertanian organik mengandalkan bahan-bahan alami dan menghindari segala asupan sintetik, baik berupa pupuk sintetik, herbisida, maupun pestisida sintetik.

Kendala dalam pemenuhan pupuk anorganik antara lain disebabkan dengan semakin mahalnya harga pupuk sangat dirasakan penduduk Sumber Sari, sedangkan tekanan ekonomi yang semakin menghimpit dewasa ini membuat lebih sulitnya penduduk untuk membeli pupuk anorganik. Pemberian yang intensif bahan-bahan kimia terhadap tanah dan tanaman akan menyebabkan terjadinya penurunan produktivitas lahan yang selanjutnya menurunkan produksi tanaman (Clifton, 2013).

Salah satu upaya pemulihan lahan secara berkelanjutan dengan menerapkan sistem pertanian organik antara lain dengan pemberian pupuk organik yang berbahan dasar dari limbah pertanian dan sampah rumah tangga yang banyak tersedia di wilayah namun masyarakat belum memanfaatan secara optimal. Melalui kegiatan ini diharapkan dapat memberikan infor-masi dan pengetahuan tentang pemanfaatan pupuk organik terutama limbah pertanian dalam upaya untuk memulihkan lahan yang sudah tercemar bahan-bahan kimia dari pestisida maupun pupuk anorganik yang intensif penggunaannya.

Upaya meningkatkan produksi tanaman khususnya padi pada umumnya masyarakat atau petani dilakukan 
melalui penggunaan input eksternal secara intensif (pupuk anorganik dan pestisida). Untuk menghasilkan sekitar 4-6 ton/ha diperlukan pupuk sekitar 200-300 kg urea, SP$100 \mathrm{~kg}$ dan $\mathrm{KCl} 100 \mathrm{~kg}$ per hektar. Penggunaan pupuk anorganik secara intensif akan memacu mineralisasi bahan organik tanah sehingga menyebabkan terjadinya penurunan kadar C-organik dalam tanah. Hasil berbagai kajian menunjukkan bahwa kadar C-organik pada lahanlahan sawah di sentra produksi padi umumnya sudah rendah $(<2 \%)$. Lahan sawah dengan kadar C-organik $<2 \%$ sudah merupakan indikasi terjadinya penurunan kualitas tanah atau dapat dikatakan bahwa tanah itu tidak sehat. Akibatnya, walaupun dosis pupuk anorganik ditingkatkan, tetapi tidak memberikan kenaikan hasil yang signifikan. ( Hasil penelitian menunjukkan aplikasi pupuk hayati MPF dapat meningkatkan pertumbuhan dan hasil jagung (Fitriatin, dkk.,2013) serta dapat mengurangi kebutuhan pupuk P (Fitriatin, dkk., 2014)

Kendala dalam pemenuhan pupuk anorganik antara lain disebabkan dengan semakin mahalnya harga pupuk sangat dirasakan penduduk Sumber Sari, sedangkan tekanan ekonomi yang semakin menghimpit dewasa ini membuat lebih sulitnya penduduk untuk membeli pupuk anorganik. Pemberian yang intensif bahan-bahan kimia terhadap tanah dan tanaman akan menyebabkan terjadinya penurunan produktivitas lahan yang selanjutnya menurunkan produksi tanaman.

Salah satu upaya pemulihan lahan secara berkelanjutan antara lain dengan pemberian pupuk organik yang berbahan dasar dari limbah pertanian dan sampah rumah tangga yang banyak tersedia di wilayah namun masyarakat belum memanfaatan secara optimal. Melalui kegiatan ini diharapkan dapat memberikan informasi dan pengetahuan tentang pemanfaatan pupuk organik terutama limbah pertanian dan MOL (mikroorganisme lokal) dalam upaya untuk memulihkan lahan yang sudah tercemar bahan-bahan kimia dari pestisida maupun pupuk anorganik yang intensif penggunaannya.

\section{METODE}

Impelementasi pemberdayaan masyarakat dalam bentuk demonstrasi plot (demplot) budidaya padi sawah berbasis Pertanian Organik dilakukan di Desa Sumber Sari Kec. Ciparay Kabupaten Bandung. Luas lahan demplot terdiri dari tiga petak dengan ukuran per petak adalah $3 \mathrm{mx} 4 \mathrm{~m}$

Demplot terdiri atas tiga perlakuan yaitu budidaya padi sawah varietas Ciherang yaitu sistem organik (100\% organik) ; semi organik ( $50 \%$ anorganik $+50 \%$ organik) dan cara konvensional (100\% anorganik).. Rincian setiap perlakuan adalah sebagai

1) Sistem Organik : pemmberian bahan organik yang digunakan adalah kompos dengan dosis $70 \mathrm{~kg}$ per petak atau setara dengan 2 ton/ha (tanpa pupuk anorganik), dengan empat kali penyemprotan MOL $(10,20,30$ dan 40 HST $)$
2) Semi Organik: pemberian bahan organik $1 / 2$ dosis yaitu $15 \mathrm{~kg}$ per petak atau setara dengan 1 ton/ha dengan pemberian pupuk NPK $1 / 2$ dosis rekomendasi Penyemprotan MOL $1 / 2$ dosis dari perlakuan full organik

3) Full Anorganik: pemberian pupuk NPK 1 dosis rekomendasi yaitu $30 \mathrm{~kg}$ per petak.

Pengamatan dilakukan terhadap pertumbuhan padi berupa jumlah anakan (diamati secara periodik pada umur 21, 28, 35 da 42 hari setelah tanam) serta hasil panen (ubinan).

\section{HASIL DAN PEMBAHASAN}

Petak perlakuan organik pada usia tanaman 21 hari setelah tanam (HST), tanaman tampak lebih kurus dibanding tanaman lainnya. Namun pada petak yang semi organik tanaman lebih hijau dan jumlah anakan lebih banyak dibandingkan dengan petak organik dan anorganik. Hal ini diduga karena pada perlakuan organik, dengan dosis yang hanya 2 ton per hektare belum mencukupi kebutuhan hara tanaman sehingga pertumbuhan tanaman belum maksimal. Sedangkan pada perlakuan semi organik memperlihatkan pertumbuhan yang lebih baik dibandingkan perlakuan lainnya menunjukan pemberian pupuk organik dapat mengurangi pupuk anorganik sampai setengah dosis rekomendasi. Pengamatan yang dilakukan selama demplot ini meliputi rata-rata jumlah anakan per rumpun (Tabel 1).

Tabel 1. Rata-rata jumlah anakan per rumpun tanaman padi pada demplot pertanian organik di Desa Sumber sari, Kec. Ciparay Kab. Bandung

\begin{tabular}{lcccc}
\hline \multicolumn{1}{c}{ Perlakuan } & 21 HST & 28 HST & 35 HST & 42 HST \\
\hline Organik & 10,8 & 14,0 & 17,9 & 18,6 \\
Semiorganik & 11,5 & 16,5 & 24,7 & 25,7 \\
Konvensional & 11,1 & 16,2 & 24,5 & 25,4 \\
\hline
\end{tabular}

Hasil panen padi sawah pada demplot sistem pertanian organik ini menunjukkan bahwa perlakuan semi organik memberikan hasil panen (berat gabah) tertinggi dibandingkan perlakuan organik dan anorganik (Tabel 2). Hal ini menunjukkan pemberian pupuk organik dapat meningkatkan hasil tanaman serta dapat mengefisienkan pupuk anorganik. Namun demikian perlakuan full organik (tanpa pupuk anorganik) menunjukkan hasil yang lebih rendah $17 \%$ dibandingkan hasil petak semi organik dan lebih rendah $11 \%$ dibanding petak anorganik. Hal ini menunjukkan potensi yang tinggi pemberian pupuk organik untuk meningkatkan hasil tanaman. Selain itu pemberian pupuk organik akan meningkatkan kualitas tanah secara fisik, kimia dan biologis (Emily, et al. 2017) 
Tabel 2. Hasil tanaman padi sawah pada demplot pertanian organik di Desa Sumber sari, Kec. Ciparay Kab. Bandung

\begin{tabular}{lc}
\hline Perlakuan & $\begin{array}{c}\text { Hasil Ubinan } \\
(\mathrm{kg} / \mathrm{ubin})\end{array}$ \\
\hline Organik & 4,01 \\
Semiorganik & 4,75 \\
Konvensional & 4,40 \\
\hline
\end{tabular}

\section{SIMPULAN}

Hasil padi sawah pada demplot simtem pertanian organik menunjukkan bahwa perlakuan semi organik memberikan hasil panen (berat gabah) tertinggi dibandingkan perlakuan organik dan konvensional (100\% anorganik). Berdasarkan hasil demplot di Desa Sumber Sari, penerapan sistem pertanian organik mampu meningkatkan hasil tanaman dan mengurangi penggunaan pupuk anorganik.

\section{UCAPAN TERIMA KASIH}

Ucapan terima kasih kepada Rektor Uniersitas Padjadjaran dan Direktur Riset dan Pengabdian pada Masyarakat UNPAD atas pendanaan kegaiatan pengabdian kepada masyarakat di Desa Sumber Sari Kecamatan Ciparay Kabupaten Bandung. Ucapan terima kasih kepada aparatur desa serta petani dan masyarat yang berpartisipasi dalam kegaiatan PKM ini. Terima kasih juga kepada mahasiswa KKN integratif tahun 2018 yang telah membantu selama kegiatan ini.

\section{DAFTAR PUSTAKA}

Clifton, E.H. 2013. Impacts of conventional and organic agriculture on soil-borne entomopathogenic fungi. Iowa State University Capstones, Theses and Dissertations. https://lib.dr.iastate.edu/ etd $/ 13370$

Emily E. Oldfield and S. A. Wood. 2017. Direct effects of soil organic matter on productivity mirror those observed with organic amendments. Plant Soil. https://doi.org/10.1007/s11104-017-3513-5

Fitriatin, B.N. A. Yuniarti, and T. Muktini. 2013. The effect of phosphate solubilizing microbe producing growth regulators to increase solubilizing of soil phosphate and yield of maize on marginal soil. Soil-Water Journal, Vol. 2 No. 2 (1) pp.547-554 (ISSN : 2146 - 7072)

Fitriatin, B.N., A. Yuniarti, and T. Turmuktini. 2014. The effect of phosphate solubilizing microbe producing growth regulators on soil phosphate, growth and yield of maize and fertilizer efficiency on Ultisol. Eurasian Journal of Soil Science Vol 3 pp. $104-107$. 